\title{
PENGARUH KEBIJAKAN DIVIDEN, KEBIJAKAN HUTANG DAN PROFITABILITAS TERHADAP NILAI PERUSAHAAN MANUFAKTUR
}

\author{
Eka Krisnawati dan Munasiron M \\ ekakrisnawati@rocketmail.com,munasiron@hotmail.com \\ Fakultas Ekonomi UPN "Veteran" Jakarta \\ Jl. RS. Fatmawati Pondok labu Jakarta Selatan 12450
}

\begin{abstract}
This study aimed to examine the effect of Dividend Policy, Policy Liabilities and Profitability of Company Value of the companies listed in Indonesia Stock Exchange period 2011 to 2014. The population in this study a number of 60 companies listed in Indonesia Stock Exchange. Data obtained from financial statements 2011 to 2014 that has been published. Obtained a total sample of 15 companies. The analysis technique used is multiple linear regression and hypothesis testing with constant 5\%.In this study occur existing data were not normally distributed, this is due to some extreme values that look very different from the value of other observations. Of the 60 samples of existing research, as many as 24 sample company data should be eliminated (outlier data). It is intended to dispose of the data extremes can cause data distribution becomes normal, so that the data is left as many as 36 samples were used.The results showed that the dividend policy has no significant effect on the value of the company, debt policy does not significantly influence the company's value and profitability significantly influence the value of the company. The coefficient of determination $R$ square indicates 0,073 or 7,3\% of explaining that the variable is explained by the variable company value and dividend policy, policy liability and profitability the remaining $92,7 \%$ is explained by other variables.
\end{abstract}

Keywords : dividend policy, policy liability, profitability and company value.

\section{PENDAHULUAN}

Dalam pendirian perusahaan, tujuan perusahaan adalah memaksimalkan nilai pemegangsaham. Nilai pemegang saham akan meningkat apabila nilai perusahaan meningkat yang ditandaidengan tingkat pengembalian investasi yang tinggi pada pemegang saham. (Jusriani dan Rahardjo 2013).Maksimisasi nilai perusahaan merupakan cara untuk memaksimalkan kekayaan pemegang saham. Tujuan maksimisasi nilai perusahaan seharusnya dijadikan landasan dalam menentukan keputusankeputusankeuanganperusahaan. Keputusan-keputusan yang ditentukan pihak manajemen perusahaan akan dapat mempengaruhi nilai perusahaan. Begitu pentingnya keputusan keuangan sehingga harus dibuat secara hati-hati, sebelum suatu keputusan ditetapkan sebaiknya manajer perusahaan mempersiapkan keputusan tersebut secara matang.(Putra 2014).

Total pengembalian (return) kepada pemegang saham selama waktu tertentu terdiri dari peningkatan 
harga saham ditambah dividen yang diterima. Jika perusahaan menetapkan dividen yang lebih tinggi dari tahun sebelumnya, maka return yang diperoleh investor akan semakin tinggi. (Mardiyati dkk.2012).

Setiap perusahaan, di satu pihak menginginkan adanya pertumbuhan bagiperusahaan, dan di lain pihak juga ingin membayarkan dividen kepada para pemegangsaham. Itulah sebabnya, manajemen perusahaan hendaknya dapat membuat kebijakandividen yang tepat, dalam artinya menentukan berapa persen laba yang harus diberikankepada para pemegang saham sebagai dividen dan berapa persen laba yang harus ditahanuntuk mendukung pertumbuhan atau investasi, sehingga kepentingan para pemegangsaham dan perusahaan dapat terpenuhi semua (Ayuningtias 2013).

Perkembangan pasar modal yang pesat dapat membuat investor dapat lebih leluasa dalam melakukan aktivitas investasinya baik dalam pemilihan portofolio investasi pada efek yang tersedia maupun besarya jumlah yang diinvestasikan. Tujuan dan motivasi investor dalam melakukan pembelian saham adalah meningkatkan kekayaan mereka dimasa mendatang, yaitu dengan memperoleh hasil berupa deviden maupun capital gain yang jumlahnya diharapkan lebih besar dari tingkat return sarana investasi lain seperti deposito dan pembelian obligasi. (Putra 2014).

Suatu perusahaan untuk dapat melangsungkan aktivitas operasinya, haruslah berada dalam keadaan yang menguntungkan/profitable. Tanpa adanya keuntungan akan sulit bagi perusahaan untuk menarik modal dari luar. Perusahaan yang memiliki tingkat profitabilitas yang tinggi akan diminati sahamnya oleh investor. Sehingga, dengan demikian profitabilitas dapat mempengaruhi nilai perusahaan.(Mardiyati dkk 2012).

Selain adanya fenomena emperis, juga terdapat adayanya gap research dalam penelitian ini, dimana berdasarkan hasil penelitian terdahulu menunjukan beberapa variabel yang berpengaruh terhadap Nilai Perusahaan.

Variabel kebijakan dividen adalah Kebijakan perusahaan apakah akan membayar atau tidak,menentukan besarnya dividen dan membayar dividen lebih dari periode sebelumnya (Jusriani \&Rahardjo 2013).Wijaya \& wibawa (2010) dan Jusriani \& Rahardjo (2013) berpengaruh positif signifikan terhadap nilai perusahaan.Sedangkan Mardiyati dkk (2012) menyatakan bahwa kebijakan dividen tidak berpengaruh signifikan terhadap nilai perusahaan.Hal ini terjadi karena rasio pembayaran dividen hanyalah rincian dan tidak mempengaruhi kesejahteraan pemegang saham.

Kebijakan dividen tidak mempengaruhi harga saham dan tingkat pengembalian atas ekuitas yang diminta. Hal ini menunjukan bahwa investor lebih menyukai dividen pasti saat ini dibandingkan dengan keuntugan modal yang tidak pasti dimasa depan.

Houston (2011, hlm.211) menegaskan 'Kebijakan dividen tidak berdampak pada harga saham maupun 
biaya modal suatu perusahaan, Karena membuktikan bahwa nilai suatu perusahaan hanya ditentukan oleh profitabilitas dasar dan resiko usahanya'.

\section{Nilai Perusahaan}

Prasetyo (2011,hlm.

menegaskan 'tujuan utama perusahaan adalah memaksimumkan nilai perusahaan. nilai perusahaan yang terjadi menunjukan cara pandangan terhadap nilai perusahaan yang berbeda'.

\section{Sudana}

(2011,hlm.8)

menjelaskan 'nilai perusahaan merupakan nilai sekarang dari arus pendapatan atau kas yang diharapkan diterima dimasa yang akan datang'.

$$
\text { Putra (2014, hlm.393) }
$$

menegaskan 'nilai perusahaan didefinisikan sebagai persepsi investor terhadap tingkat keberhasilan perusahaan dalam mengelola sumber daya yang akan terlihat pada harga sahamnya'.

Dari beberapa definisi diatas bahwa nilai perusahaan adalah Memaksimalkan nilai perusahaan sangat penting artinya bagi suatu perusahaan, karena dengan memaksimalkan nilai perusahaan berarti juga memaksimalkan kemakmuran pemegang saham yang merupakan tujuan perusahaan.

Kebijakan dividen sering dianggap sebagai bagian dari keputusan pembelajaan, khususnya pembelajaan internal. Hal ini terjadi karena semakin besar dividen yang dibayarkan kepada sebagai pemegang saham, semakin kecil laba yang ditahan, dan sebaliknya.
Stice (2009, hlm. 138 ) menyimpulkan 'Dividen merupakan pembagian kepada pemegang saham dari suatu perusahaan secara proporsional sesuai dengan jumlah lembar saham yang dipegang oleh masing-masing pemilik'.

Tampubolon (2012, hlm.201) menyimpulkan 'Kebijakan dividen dibayarkan baik dalam cash maupun dalam bentuk saham. Saham hanya akan dibayarkan diluar laba ditahan dan tidak dari modal yang ditanamkan yang berbrntuk modal saham (capital stock) atau dari kelebihan yang diterima diatas nilai par'.

Harmono (2011, hlm.12) menjelaskan 'Kebijakan dividen adalah presentase laba yang dibayarkan kepada para pemegang saham dalam bentuk dividen tunai, penjagaan stabilitas dividen dari waktu ke waktu'.

Kebijakan deviden didefinisikan sebagai kebijakan yang terkait dengan pembayaran dividen oleh perusahaan, berupa penentuan besarnya pembayaran dan besarnya laba yang ditahan untuk kepentingan perusahaan.

Dalam pengambilan keputusan penggunaan pendanaan hutang tentunya harus dapat mempertimbangkan besarnya bunga yang timbul akibat besarnya biaya tetap yang nantinya akan menyebabkan semakin meningkatnya financial leverage dan semakin tidak kepastiannya tingkat pengembalian.

Harjito dan Martono ( 2005, hlm. 5) menjelaskan 'Keputusan pendanaan adalah penetapan perusahaan dalam menggunakan modal yang berasal dari hutang 
dengan menerbitkan obligasi atau penggunaan modal sendiri dengan menerbitkan saham baru.'

Nafarin (2008, hlm.342) menegaskan bahwa 'utang adalah kewajiban debitor (peminjam) untuk melaksanakn sesuatu kepada kreditur (pemberi pinjaman) selama jangka waktu tertenti'.

Rasio profitabilitas merupakan rasio untuk menilai kemampuan perusahaan dalam mencari keuntungan. Hal ini ditunjukan oleh laba yangdihasilkan dari penjualan dan pendapatan investasi. (Kasmir 2014 ,hlm.196).

Rasio profitabilitas adalah mengambarkan kemampuan perusahaan mendapatkan laba melalui semua kemampuan dan sumber yang ada seperti penjualan, kas, modal, jumlah karyawan, jumlah cabang dan sebagainya. (Harahap 2011,hlm.304).

Rasio profitabilitas adalah penilaian kinerja perusahaan yang menunjukan hasil akhir dari sejumlah kebijakan dan keputusan yang diambil manajemen perusahaan. ( Rudianto 2013, hlm.191)

Permasalahan dalam penelitian ini adalah apakah kebijakan dividen, kebijakan hutang dan profitabilitas berpengaruh terdadap nilai perusahaan.

\section{Metode Penelitian}

\section{Populasi dan Teknik Pengambilan Sampel}

Populasi yang menjadi objek dalam penelitian ini adalah perusahaan manufaktursektor industri barang kosumsi yang terdaftar di Bursa Efek Indonesia (BEI). Periode pengamatan dalam penelitian ini tahun 2011-2014.
Sempel yang digunakan dalam penelitian ini adalah perusahaan manufaktur yang terdaftar di Bursa Efek Indonesia (BEI) pada periode 2011-2014. Tehnik penentuan sampel yang digunakan dalam penelitian ini dengan menggunakan metode purposive sampling, yaitu pemilihan sampel perusahaan selama periode penelitian berdasarkan kriteria tertentu.

\section{Definisi Operasional Variabel}

Nilai perusahaan didefinisikan sebagai persepsi investor terhadap tingkat keberhasilan perusahaan dalam mengelola sumber daya yang akan terlihat pada harga sahamnya (Putra 2014).

Alat ukur yang digunakan nilai perusahaan dalam penelitian ini adalah Price Book Value.Price Book Value mengukur nilai yang diberikan pasar keuangan kepada manajemen dan organisasi perusahaan sebuah perusahaan yang terus tumbuh (Sitanggang 2012, hlm.34).Dengan formulasi sebagai berikut (Sitanggang 2012, hlm. 34).

$$
\begin{gathered}
\text { PriceBookValue }(P B V)=\frac{\text { MarketPricepershare }}{\text { BookValuepershere }} \\
\text { Variabel independen dalam }
\end{gathered}
$$
penelitian ini adalah kebijakan dividen, kebijakan hutang dan profitabilitas.

1. Kebijakan Dividen (X1)

Dividen

merupakan pembagian kepada pemegang saham dari suatu perusahaan secara proporsional sesuai dengan jumlah lembar saham yang dipegang oleh masing-masing pemilik.(Stice 2009, hlm. 138). 
Alat ukur yang digunakan kebijakan dividen dalam penelitian ini adalah Deviden Payout Ratio.Dividend Payout Ratio yaitu Dividend Payout Ratioakan mengikuti naik turunya Earning Per Share. Nilai Dividen Per Share akan naik turun tergantung pada nilai Earning Per Share(Sitanggang 2013,hlm. 185).

Dengan formulasi sebagai berikut (Sitanggang 2013,hlm. 185)

Dividedn Payout Ratio $(\mathrm{DPR})=\frac{\text { DividenPerShare }}{\text { EarningPerShare }}$ Hutang adalah besarnya porsi utang yang ada diperusahaan jika dibandingkan dengan modal atau aset yang ada (Gumanti 2011, hlm.113).

Alat ukur yang digunakan kebijakan hutang dalam penelitian ini adalah Debt to Equity Ratio.Debt to Equity Ratioyaitu rasio antara total utang dengan total ekuitas dalam perusahaan yang memberi gambaran perbandingan antara total utang dengan modal sendiri. (Sitanggang 2012).hlm.26). Dengan formulasi sebagai berikut (Sitanggang 2012, hlm 26).

Debttoequityratio $($ DER $)=\frac{\text { Totalliability }}{\text { Totalequity }}$

Rasio profitabilitas merupakan rasio untuk menilai kemampuan perusahaan dalam mencari keuntungan.Hal ini ditunjukan oleh laba yangdihasilkan dari penjualan dan pendapatan investasi. (Kasmir 2011,hlm.196).
Alat ukur yang digunakan profitabilitas dalam penelitian iniadalah Retrun On Equity. Retrun On Equity yaitu kemampuan perusahaan memperoleh laba dalam hubungannya dengan modal sendiri.(Kasmir 2011, hlm.204).

Dengan formulasi sebgai berikut (Kasmir 2011, hlm. 204).

Retrun On Equity $(\mathrm{ROE})=\frac{\text { EarningAfterTax }}{\text { Equity }}$

\section{Hasil dan Pembahasan \\ Hasil Statistik Deskriptif}

Tehnik analisis yang digunakan dalam melakukan pengujian hipotesis dalam penelitian ini adalah analisis regresi linier berganda. Analisis in dilakukan untuk mengetahui ada tidaknya pengaruh kebijakan dividen, kebijakan hutang dan profitabilitas sebagai variabel independen terhdap nilai perusahaan sebagai variabel dependen. Alat bantu yang digunakan untuk menganalisi penelitian ini yaitu SPSS (Statistical Product and Service Solution) for windows version 20.0. Untuk mempermudah dalam perhitungan. sebagai berikut: 
Tabel 5 Statistik Deskriptif

\begin{tabular}{lcrrrr}
\hline & \multicolumn{6}{c}{ Descriptive Statistics } \\
\hline & $\mathrm{N}$ & Min & Max & Mean & $\begin{array}{c}\text { Std. } \\
\text { Deviation }\end{array}$ \\
Kebijakan & 36 & .00194 & 1.78326 & .4616986 & .33255093 \\
$\begin{array}{l}\text { Dividen } \\
\text { Kebijakan Hutang }\end{array}$ & 36 & .10824 & 1.72196 & .5631817 & .42746371 \\
Profitabilitas & 36 & .13538 & .44678 & .2153625 & .08901086 \\
Nilai Perusahaan & 36 & .00177 & 10.47885 & 3.5050219 & 2.37101815 \\
Valid N (listwise) & 36 & & & & \\
\hline
\end{tabular}

Sumber: Hasil output SPSS

Dari tabel 5 diatas dapat diketahui bahwa jumlah sampel yang digunakan dalam penelitian ini adalah sebanyak 36. perusahaan industri dasar dan kimiayang terdaftar di BEI pada periode 2011-2014. Nilai minimum variabel Kebijakan Dividen sebesar 0,00194 terdapat pada PT. Nippon Indosari Corpindo Tbk tahun 2012 dimana nilai dividen pershare sebesar 28,62928 dan earnings per share sebesar 14.733. Sedangkan nilai maksimum Kebijakan Dividen sebesar 1,78326 terdapat pada PT. Kalbe Farma Tbktahun 2014 dimana dividen pershare sebesar 78,46356 dan earnings per share sebesar 44. Nilai rata-rata kebijakan dividen sebesar 0,4616986 dan standar deviasi sebesar 0,33255093 . Nilai standar deviasi lebih rendah dari nilai rata-rata (mean) menunjukan adanya nilai variansi kebijakan dividen kecil atau adanya kesenjangan yang rendah dari kebijakan dividen terrendah dan tertinggi. (Lampiran-1).

Selanjutnya variabel Kebijakan Hutang memiliki nilai minimum sebesar 0,10824yang ditunjukkan pada PT. Mandom Indonesia Tbk. tahun 2011 dan nilai maksimum sebesar 1,72196 yang ditunjukkan pada PT. Mayora Indah Tbktahun 2011. Nilai rata-rata Kebijakan Hutang sebesar 0,5631817 serta standar deviasi sebesar 0,4274637 . Nilai standar deviasi lebih rendah dari nilai rata-rata (mean) menunjukan adanya nilai variansi kebijakan hutang kecil atau adanya kesenjangan yang rendah dari kebijakan hutang terrendah dan tertinggi. (Lampiran 2).

Variabel profitabilitas memiliki nilai minimum sebesar 0,13538 yang ditunjukkan pada PT. Mandom Indonesia Tbktahun 2013dan nilai maksimum sebesar 0,44678 yang ditunjukkan pada PT. Taisho Pharmaceutical IndonesiaTbk tahun 2014. Nilai rata-rata variabel profitabilitas sebesar 0,2153625 serta standar deviasi sebesar 0,08901086. Nilai standar deviasi lebih rendah dari nilai rata-rata (mean) menunjukkan adanya nilai variansi profitabilitas kecil atau adanya kesenjangan yang rendah dari profitabilitas terrendah dan tertinggi. (Lampiran 3).

Variabel nilai perusahaan memiliki nilai minimum sebesar 0,00177 yang ditunjukkan padaPT. Darya-Varia Laboratoria Tbktahun 2011dan nilai maksimum sebesar 10,47885 yang ditunjukkan pada PT. Nippon Indosari Corpindo Tbktahun 2012. Nilai rata-rata variabel Nilai 
Perusahaan sebesar 3,5050129 serta standar deviasi sebesar 2,37101815. Nilai standar deviasi lebih rendah dari nilai rata-rata (mean) menunjukkan adanya nilai variansi nilai perusahaan kecil atau adanya kesenjangan yang rendah dari nilai perusahaan terrendah dan tertinggi. (Lampiran 4).

\section{Uji Asumsi Klasik}

pengujian asumsi klasik yang digunakan adalah uji normalitas, autokolerasi, heteroskedastisitas dan multikolonieritas yang secara rinci dapat dijelaskan sebagai berikut:

\section{Uji Normalitas}

Tabel 6 Hasil Uji olmogrov - Smirnov

\begin{tabular}{|c|c|c|c|c|c|}
\hline \multicolumn{6}{|c|}{ One-Sample Kolmogorov-Smirnov Test } \\
\hline & & $\begin{array}{c}\text { Kebijakan } \\
\text { Dividen }\end{array}$ & $\begin{array}{l}\text { Kebijakan } \\
\text { Hutang }\end{array}$ & Profitabilitas & Nilai Perusahaan \\
\hline $\mathrm{N}$ & & 36 & 36 & 36 & 36 \\
\hline Normal & Mean & .4616986 & .5631817 & .2153625 & 3.5050219 \\
\hline Parameters ${ }^{\mathrm{a} b}$ & Std. Deviation & .33255093 & .42746371 & .08901086 & 2.37101815 \\
\hline Most Extreme & Absolute & .194 & .193 & .227 & .095 \\
\hline \multirow[t]{2}{*}{ Differences } & Positive & 194 & .193 & .227 & .095 \\
\hline & Negative & -.083 & -.144 & -.184 & -.070 \\
\hline \multicolumn{2}{|c|}{ Kolmogorov-Smirnov Z } & 1.167 & 1.159 & 1.359 & .571 \\
\hline $\begin{array}{l}\text { Asymp. Sig. (2 } \\
\text { a. Test distribut } \\
\text { b. Calculated fr }\end{array}$ & Normal. & .131 & .136 & .050 & .900 \\
\hline
\end{tabular}

\section{Uji Autokolerasi}

Tabel 7 Hasil Uji Autokorelasi

(Durbin-Watson) Model Summary ${ }^{b}$

\begin{tabular}{lc}
\hline Model & \multicolumn{1}{c}{ Durbin-Watson } \\
\hline 1 & 2.330 \\
a. Predictors: (Constant), Profitabilitas, & Kebijakan Hutang, Kebijakan Dividen \\
b. Dependent Variable: Nilai Perusahaan
\end{tabular}

Berdasarkan hasil uji autokorelasi pada tabel 7 diatas menunjukan nilai Durbin-Watson sebesar 2.330. Dengan signifikansi 5\%, jumlah sampel 37 (n), dan jumlah variabel independen $3 \quad(\mathrm{~K}=3)$ maka diperoleh nilai dl 12953 dan du 1.6539. Nilai dw 2.330 lebih besar dari batas bawah atau du yaitu 1.6539. Untuk memutuskan hasil uji autokorelasi dapat dilihat dengan du $<\mathrm{dw}<4-\mathrm{du}$,maka diperoleh 1.6539 $<2.330<2.7047$ yang berarti keputusan tidak ditolak dan tidak terdapat autokorelasi positif atau negatif antar residual.

\section{Uji Multikolonieritas}

Tabel 8 Hasil Uji ultikolonieritas

Tabel 8 Hasil Uji Multikolonieritas

\begin{tabular}{llrc}
\hline Model & \multicolumn{2}{c}{ Collinearity Statistics } \\
\cline { 3 - 4 } 1 & Tolerance & VIF \\
& Kebijakant) & & \\
& Kebijakan Hutiden & .603 & 1.658 \\
& Profitabilitas & .707 & 1.414 \\
\hline
\end{tabular}

a. Dependent Variable: Nilai Perusahaan Sumber : Data sekunder yang telah diolah

Dari tabel 8 diatas, dapat diihat bahwa nilai Variance Inflation Factor (VIF) dari masing-masing variabel independen tidak memiliki nilai yang lebih dari 10 dan tolerance value $>$ 0.10 , sehingga hal ini menandakan bahwa model regresi yang terdapat di dalam penelitian ini tidak mengandung multikolonieritas. 


\section{Uji Heteroskedastisitas}

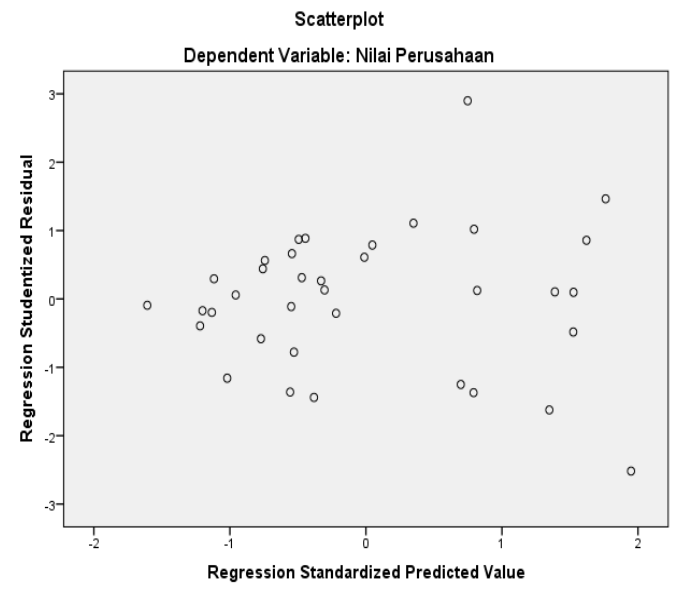

Sumber : Data sekunder yang telah diolah

\section{Gambar 3 Hasil Grafik Scatterplot Uji}

Hasil uji heteroskedastisitas berdasarkan grafik Scatterplot pada gambar 3 menunjukkan bahwa titiktitik pada grafik menyebar di atas dan di bawah angka 0 pada sumbu $Y$ dan tidak terdapat pola tertentu. Hal tersebut mengindikasikan tidak terjadinya gangguan heteroskedastisitas.

\section{Uji Hipotesis}

Uji hipotesis dapat dilakukan apabila terpenuhinya uji asumsi klasik. Dengan terpenuhinya uji asumsi klasik tersebut diatas, maka tidak terdapat kesalahan atau penyimpangan uji asumsi klasik, sehingga dapat melanjutkan pengujian hipotesis dengan menggunakan Uji Simultan (Uji F), Uji Koefisien Determinasi (R Square), Uji Parsial (Uji T), dan model regresi berganda. Analisis ini bertujuan untuk mengetahui ada atau tidaknya pengaruh Kebijakan Dividen, Kebijakan Hutang dan Profitabilitas sebagai variabel bebas (independent variable) terhadap Nilai Perusahaan sebagai variabel terikat (dependent variable). Untuk menguji kesalahan model regresi yang digunakan dalam penelitian, maka harus dilakukan uji $\mathrm{F}$, uji $\mathrm{R}^{2}$, dan uji $\mathrm{T}$.

\section{Uji F}

\begin{tabular}{|c|c|c|c|c|}
\hline \multicolumn{5}{|c|}{ Tabel 9 Hasil Uji Simultan } \\
\hline \multicolumn{2}{|c|}{ Model } & $\mathrm{F}$ & Sig & \\
\hline \multirow[t]{3}{*}{1} & Regression & 1.924 & & $.146^{\mathrm{b}}$ \\
\hline & Residual & & & \\
\hline & Total & & & \\
\hline \multicolumn{5}{|c|}{ a. Dependent Variable: Nilai Perusahaan } \\
\hline \multicolumn{5}{|c|}{$\begin{array}{l}\text { b. Predictors: (Constant), Profitabilitas, } \\
\text { Kebijakan Hutang, Kebijakan Dividen }\end{array}$} \\
\hline
\end{tabular}

Pada tabel uji simultan (uji F) menunjukkan bahwa nilai tingkat signifikansi sebesar $0.146 \quad(14.6 \%)$ lebih besar dari a $=0.05(5 \%)$ atau $0.146(14.6 \%)<0.05(5 \%)$, hal ini berarti bahwa Ho diterima dan $\mathrm{Ha}$ ditolak sehingga dapat disimpulkan bahwa Kebijakan Dividen, Kebijakan Hutang, Profitabilitas secara bersamasama (simultan) tidak memiliki pengaruh yang signifikan terhadap Nilai Perusahaan. 
Uji $\mathbf{R}^{2}$ (Uji Koefisien Determinasi)

\begin{tabular}{lc}
\multicolumn{2}{l}{ Model Summary $^{\mathbf{b}}$} \\
\hline Mode & Adjusted R \\
1 & Square \\
1 & .073 \\
\hline
\end{tabular}

Berdasarkan tabel 10 diatas menunjukkan bahwa nilai adjusted $\mathrm{R}$ Square $\left(\mathrm{R}^{2}\right)$ adalah sebesar 0.073 atau $7.3 \%$. Sehingga hal ini menunjukkan bahwa persentase pengaruh variabel independen (Kebijakan Dividen, Kebijakan Hutang, Profitabilitas) terhadap variabel dependen (Nilai Perusahaan) sebesar $7.3 \%$, sisanya $92,7 \%$ dipengaruhi oleh variabel lain yang tidak dimasukkan kedalam penelitian ini atau faktor-faktor lain yang lebih dominan.

Uji t (Uji Parsial)

Tabel 11 hasil uji parsial ( Uji t) Tab

\begin{tabular}{|c|c|c|}
\hline Model & $\mathbf{t}$ & Sig. \\
\hline (Constant) & .999 & .325 \\
\hline Kebijakan & -.670 & .508 \\
\hline Dividen & & \\
\hline Kebijakan & .546 & .589 \\
\hline Hutang & & \\
\hline Profitabilitas & 2.250 & .031 \\
\hline $\begin{array}{l}\text { a. Dependent } \\
\text { Perusahaan }\end{array}$ & Variable: & Nilai \\
\hline
\end{tabular}

Berdasarkan tabel diatas, menunjukkan bahwa variabel Kebijakan Dividen mempunyai tingkat signifikan sebesar 0.508 (50.8\%) lebih besar dari taraf signifikan sebesar 0,05 (5\%). Hal ini berarti bahwa Ho diterima dan $\mathrm{Ha}$ ditolak sehingga dapat disimpulkan bahwa Kebijakan Dividentidak memiliki pengaruh yang signifikan terhadap Nilai Perusahaan.
Variabel Kebijakan Hutang mempunyai tingkat signifikan sebesar 0.589 (58.9\%) lebih besar dari 0,05 $(5 \%)$. Hal ini berarti bahwa Ho diterima dan $\mathrm{Ha}$ ditolak, sehingga dapat disimpulkan bahwa Kebijakan Hutang tidak memiliki pengaruh yang signifikan terhadap Nilai Perusahaan..

Sedangkan variabel Profitabilitas sebesar $0.031 \quad(3 ., 1 \%)$ lebih kecil dari 0,05 (5\%). Hal ini berarti bahwa Ho ditolak dan $\mathrm{Ha}$ diterima sehingga dapat disimpulkan bahwa Profitabilitas berpengaruh signifikan terhadap Nilai Perusahaan.

\section{Model Regresi}

Tabel 12 Hasil Uji Persamaan Regresi Berganda

\begin{tabular}{|c|c|c|c|}
\hline \multirow{2}{*}{\multicolumn{2}{|c|}{ Model }} & \multicolumn{2}{|c|}{$\begin{array}{c}\text { Unstandardized } \\
\text { Coefficients }\end{array}$} \\
\hline & & $\mathrm{B}$ & $\begin{array}{l}\text { Std. } \\
\text { Error }\end{array}$ \\
\hline \multirow[t]{4}{*}{1} & (Constant) & 1.330 & 1.331 \\
\hline & $\begin{array}{l}\text { Kebijakan } \\
\text { Dividen }\end{array}$ & -1.001 & 1.494 \\
\hline & $\begin{array}{l}\text { Kebijakan } \\
\text { Hutang }\end{array}$ & .586 & 1.073 \\
\hline & Profitabilitas & 10.715 & 4.762 \\
\hline
\end{tabular}

a. Dependent Variable: Nilai

Perusahaan

Berdasarkan tabel diatas, maka dapat diperoleh persamaan regresi sebagai berikut :

$$
\begin{aligned}
\mathrm{PBV}= & 1.330-1.001 \mathrm{DPR}+0.586 \mathrm{DER} \\
& +10.715 \mathrm{ROE}
\end{aligned}
$$

Dari persamaan regresi di atas, diketahui bahwa nilai konstanta sebesar 1.330. Hal ini menunjukkan bahwa jika kebijakan dividen, kebijakan hutang dan profitabilitas adalah 0 atau konstan, maka nilai perusahaan adalah sebesar 1.330. 
Persamaan regresi untuk nilai kebijakan dividen $\left(\mathrm{X}_{1}\right)$ sebesar -1.001 mempunyai arti bahwa setiap kenaikan kebijakan dividen sebesar 1 dengan asumsi variabel lain tetap, maka akan menyebabkan kenaikan nilai perusahaan sebesar 1.001 .

Persamaan regresi untuk nilai kebijakan hutang $\left(\mathrm{X}_{2}\right)$ sebesar 0.586 mempunyai arti bahwa setiap kenaikan kebijakan hutang sebesar 1 dengan asumsi variabel lain tetap, maka akan menyebabkan penurunan nilai perusahaan sebesar 0.586 .

Persamaan regresi untuk nilai profitabilitas $\left(\mathrm{X}_{3}\right)$ sebesar 10.715 mempunyai arti bahwa setiap kenaikan profitabilitas sebesar 1 dengan asumsi variabel lain tetap, maka akan menyebabkan kenaikan nilai perusahaan sebesar 10.715 .

\section{Simpulan dan Saran Simpulan}

Tujuan penelitian ini adalah untuk menguji apakah terdapat pengaruh kebijakan dividen, kebijakan hutang dan profitabilitas terhadap nilai perusahaan pada perusahaan industri dasar dan kimia yang terdaftar di Bursa Efek Indonesia (BEI) pada tahun 2011 sampai 2014.

Berdasarkan analisis dan pembahasan yang telah di uraikan pada bab-bab sebelumnya serta pengujian yang telah dilakukan maka dapat diambil kesimpulan sebagai berikut :

a. Secara simultan variabel independen yang terdiri dari Kebijakan Dividen, Kebijakan Hutang, Profitabilitas secara bersama-sama tidak memiliki pengaruh yang signifikan terhadap
Nilai Perusahaan.Dengan demikian maka hipotesis penelitian terbukti.

b. Secara parsial kebijakan dividen tidak berpengaruh secara signifikan terhadap nilai perusahaan dan secara parsial kebijakan hutang tidak berpengaruh signifikan terhadap nilai perusaan. Dan secara parsial profitabilitas berpengaruh signifikan terhadap nilai perusahaan. Kondisi ini mengandung arti bahwa perusahaan industi dasar dan kimiayang beroperasi pada tahun tersebut mampu mengelola aktiva lancarnyasecara optimal.

c. Melalui uji koefisien determinasi (R2), diketahui bahwa kebijakan dividen, kebijakan hutang dan profitabilitas mempunyai pengaruh sebesar 32,9\% terhadap nilai perusahaan, sedangkan $67,1 \%$ dipengaruhi oleh variabel lain.

\section{Saran}

Saran yang dapat diberikan untuk perusahaan yaitu hendaknya lebih meningkatkan nilai perusahaan melalui penjualan dengan cara melakukan promosi secara maksimal dan perusahaan juga diharapkan menjaga rasio utangnya dengan cara tidak menambah utang yang ada agar biaya tetap yang dikeluarkan perusahaan untuk membayar utang relatif kecil sehingga tidak menurunkan nilai perusahaan. Selain itu perusahaan juga harus mampu mengendalikan kebijakan hutang dengan cara mengurangi hutang melalui peinjaman yang berlebihan agar tidak terjadi kebangkrutan. 
DAFTAR PUSTAKA

Ayuningtias, D \& Kurnia 2013, 'Pengaruh Profitabilitas terhadap Nilai Perusahaan Kebijakan Dividend dan Kesempatan Investasi sebagai Variabel Antara', Jurnal Ilmu dan Riset Akuntansi, Vol,1. No.1, hlm.3940.

Brigham, EF \& Houston,JF 2010, Dasar - dasar manjemen keuangan, Edisi 11, Salemba Empat: Jakarta.

Brigham, EF \& Houston, JF 2011, Dasar-dasar manajemen keuangan. Edisi 11, penerbit Salemba Empat, Jakarta.

Fahmi,I, 2012, Pengantar pasar modal. Penerbit Alfabeta : Bandung.

Gill, A \& John,DO 2012,'The Impact of Corporate Govermance and Financial Leverage on the Value of American Firms', International Research Journal of Finance and Economics. Hal.1-14.

Ghozali, I 2011, Aplikasi Analisis Multivariabel dengan program IBM SPSS 19, Badan Penerbit Universitas Diponegoro : Semarang.

Gumanti, TA 2011, Manajemen Investasi Konsep Teori dan Aplikasi. Penerbit Mitra Wacana Media: Jakarta.

http://www.merdeka.com/uang/labaturun-41-persen-holcim-bagidividen-2013-rp-695-m.html

Hanafi, MM 2012, Manajemen Keuangan penerbit BPFE: Yogyakarta.

Harahap SS 2011. Analisis kritis laporan keuangan. Penerbit :
PT.Raja Grafindo Persada. Jakarta.

Harjito, DA \& Martono 2012,Manajemen keuangan, edisi ke 2. Kampus fakultas ekonomi universitas islam Indonesia. Ekonomis, jogyakarta.

Harmono 2011, Manajemen Keuangan Berbasis Balance Scorecad, Bumi Askara : Jakarta.

Harrison Jr WT, Horngren, CT, Thomas CW, Suwardy, T 2011, Akuntansi keuangan' international financial reporting standart - IFRS, edisi kedelapan jilid2. Erlangga : Jakarta.

Juhendi, N, Sudarman,M, Aisjah,M, Rofiaty 2013, 'The Effect of Internal factor and Stock Ownership Structure on Dividend Policy on Company's Value [A Study on Manufacturing Cpmpanies Listed on the Indonesia Stock Exchange (IDX)], International Journal of Busimess and Management Invention, Vol.2. hlm.6.

Jusriani, IF \& Rahardo, SN 2013,'Analisis Pengaruh Profitabilitas, Kebijakan Dividen, Kebijakan Utang, dan kepemilikan Manajerial terhadap Nilai perusahaan'( Studi Empiris pada perusahaan manufaktur yang terdaftar di Bursa Efek Indonesia 2009-2011). EJournal diponegoro Journal of Accounting. Vol,2. No.2. Hal,12. 
Kasmir,SE.MM 2014, Analisi laporan keuangan. Raja grafindo persada, Jakarta.

Martono,SU \& Harjito DA 2005. 'Manajemen keuangan'. Penerbit: Ekonisia. Yogyakarta.

Mardiyati, U Dkk 2012. 'Pengaruh kebijakan Dividen, kebijakan Hutang dan Profitabilitas terhadap Nilai Perusahaan Manufaktur terdaftar di Bursa Efek Indonesia (BEI)', 20052010. Jurnal Riset Manajemen Sains Indonesia (JRMSI). Vol,3. No.1, hlm. 2-4.

Maxwell,OO \& Kehinde EF 2012, 'Capital Strukture and Firm Value: Empirical Evidence from Nigeria, International Journal of Business and Social Science, Vol. 3 No.19, October 2012.

Nafarin,M 2008. Penganggaran perusahaan. Penerbit salempa empat : Jakarta.

Prasetyo AH 2011,Valuasi perusahaan. Jakarta. PPM

Putra, NWA 2014, 'Pengaruh Faktor Fundamental pada Nilai Perusahaan sector Telekomunikasi di Bursa Efek Indonesia'. E-Jurnal Akuntansi Universitas Udayana. Vol,8. No.3, hlm. 386-393.

Ruan, W, Gary, T \& Shinguang, M 2011. Managerial Ownership, Capital Structure and Firm Value: Evidence from China's Civilian-run Firms, Australasian Accounting, Business and Finance Journal. Volume 5.

Rudianto 2013. Akuntansi manajemen (informasi untuk pengambilan strategi).Penerbit : Erlangga. Jakarta.
Samsul, M 2006, Pasar modal dan manajemen portofolio, penerbit Erlangga : Jakarta.

Sitanggang, JP 2012,Manajemen keuangan perusahaan (dilengkapi soal dan penyelesaian). Mitra wacana media : Jakarta.

Sitanggang, JP 2013,Manajemen keuangan perusahaan lanjutan (dilengkapi soal dan penyelesaian). Mitra wacana media: Jakarta.

Sudana, IM 2011, Manajemen keuangan perusahaan. Penerbit Erlangga: Jakarta.

Sugiono 2012, Metode Penelitian Bisnis, Penerbit Alfabeta : Bandung.

Tendalin, E 2012. Portofolio dan investasi teori dan aplikasi. Yogyakarta : kanisius.

Tampubolon, MP 2013. Manajemen keuangan (finance management). Mitra wacana media : Jakarta.

Wijaya, LRP \& Wibawa, BA 2010. 'Pengaruh keputusan investasi, keputusan pendanaan dan kebijakan dividen terhadap nilai perusahaa'. Simposium Nasional Akuntansi XIII Purwokerto. 